\title{
パルスプラズマ中の二酸化岸素によるメタンカップリング及び改質
}

\author{
姚 水良 $^{1}$ - 欧陽 峰 ${ }^{1}$ 中山 明 $^{1}$

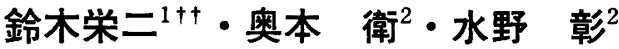

\begin{abstract}
地球環境産業技術研究機構 環境触媒研究室, 619-0292 相楽郡木津町木津川台 9-2 豊橋技術科学大学 エコロジーエ学系, 441-8580 豊橋市天伯町雲雀ヶ丘 1-1
\end{abstract}

室温および $773 \mathrm{~K}$ で大気压パルスプラズマを用いてメタン/二酸化炭素のカップリング及び改質からエ チレン, 一酸化炭素及び水素を生成する研究を行った．室温では，エチレンの選択率が最も大きい. $773 \mathrm{~K}$ で, パルス周波数が低い $\left(320 \mathrm{~s}^{-1}\right)$ 場合, エタンが主生成物であるが，パルス周波数を高く $\left(2,060 \mathrm{~s}^{-1}\right)$ すると，エチレンの選択率が高くなる．773 K と高いパルス周波数を用いて，エネルギー効率を改善でき た。

\begin{abstract}
緒言
メタンからメタノールを生産するには水蒸気を用いる改質と触 媒反応によるメタノール合成の二段階プロセスが用いられている。 しかし, 改質には $1000 \mathrm{~K}$ 以上の高温を要し, 多量のエネルギーを 消費するため (Tominaga and Yoshida, 1987)，メタンの改質を いかに低温で行うかが重要な研究課題となる，プラズマ反応によ るメタンの酸化カップリングからエチレンを生成する研究例は多 く報告されている (Suib and Zerger, 1993; Liu et al., 1997; Shepelev et al., 1993)。しかし，エネルギー効率が低いため，実 用化には至っていない，我々は，高周波数パルスのプラズマを用 い，酸素を利用したメタンの酸化カップリングと改質を試みた結 果，低パルス周波数のプラズマに比較して，メタンの転化量が多 くなり，付加価值の高いエチレンやメタノールなどが生成できる ことを見出した（Yao et al., 2000）. 天然がス中には多くの二酸 化炭素が含まれている，そこで，本研究では二酸化炭素を利用し たメタンの酸化カップリング及び改質について検討を行った。
\end{abstract}

\section{1. 実験装置および方法}

パルス電源はわれわれの仕様に基づいて作製した電源（パルス 電子技術（株）製）を用いた。パルス電源のパルス電圧の立ち上

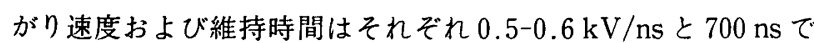
ある.プラズマ反応は同軸型反応器を用いて行った。この反応器 は内径 $10 \mathrm{~mm}$, 長さ：150 $\mathrm{mm}$ の SUS 管 (陰極) とその管の中心 に配置された外径 $0.5 \mathrm{~mm} の$ SUS 線（陽極）から構成されてい る. 反応温度が $773 \mathrm{~K}$ の場合については反応器を電気炉を用いて 加熱することにより実験を行った。メタンと二酸化炭素の混合物 (メタン：二酸化炭素 $=84: 16$, 流量 : $1.67 \times 10^{-6} \mathrm{~m}^{3} / \mathrm{s}$ ) 反応器の 上部から導入し, プラズマ反応を行った後, 反応器の下部からオ ンラインで生成物の分析を行った，炭素系生成物の分析はガスク ロマトグラフ（GC-103, OKURA RIKEN, FID）を用いて行った。 なお各生成物を FID で検出する前にメタナイザー（GL SCIENCE, MT-221）を用いてすへてての炭素系生成物を対応するアル カンに変換させた. 水素及び酸素の分析はガスクロマトグラフ （GC-280, OKURA RIKEN, TCD）を用いて行った。

\footnotetext{
$\dagger 2000$ 年 2 月 4 日受理
}

†† esuzuki@rite.or.jp
メタンと二酸化炭素の転化率, 各生成物の選択率の計算方法は以 下に示す。

$\mathrm{CH}_{4}$ conversion $=$ $\frac{\text { moles of } \mathrm{CH}_{4} \text { before reaction-moles of } \mathrm{CH}_{4} \text { after reaction }}{\text { moles of } \mathrm{CH}_{4} \text { before reaction }}$

$\times 100 \%$

$\mathrm{CO}_{2}$ conversion $=$

moles of $\mathrm{CO}_{2}$ before reaction-moles of $\mathrm{CO}_{2}$ after reaction moles of $\mathrm{CO}_{2}$ before reaction

$\times 100 \%$

$\mathrm{CO}$ selectivity $=$

$\frac{\text { moles of } \mathrm{CO} \text { produced }}{\text { moles of } \mathrm{CH}_{4} \text { converted }+ \text { moles of } \mathrm{CO}_{2} \text { converted }} \times 100 \%$

$\mathrm{C}_{2} \mathrm{H}_{4}$ or $\mathrm{C}_{2} \mathrm{H}_{6}$ selectivity $=$

$2 \times$ moles of $\mathrm{C}_{2} \mathrm{H}_{4}$ or $\mathrm{C}_{2} \mathrm{H}_{6}$ produced

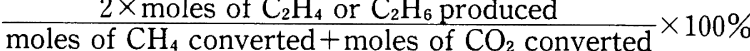

$\mathrm{H}_{2}$ selectivity $=$

moles of $\mathrm{H}_{2}$ produced $\times 100 \%$

(moles of $\mathrm{H}$ in $\mathrm{CH}_{4}$ before reaction-moles of $\mathrm{H}$ in carbon products after reaction) $/ 2$

電圧と㓌極電流の波形からプラズマに消費される電力は Eq. （6）を用いて計算した.

$$
P=F \Sigma\left(\frac{V_{1+1}+V_{1}}{2} \frac{I_{1+1}+I_{1}}{2}\left(t_{1+1}-t_{1}\right)\right)
$$

エネルギー効率（単位消費電力あたりのメタンと二酸化炭素の 転換量）は Eq. (7) で計算した.

Energy efficiency $=$

$$
\frac{F_{\mathrm{CH}_{4}} \mathrm{CH}_{4} \text { conversion }+F_{\mathrm{CO}_{2}} \mathrm{CO}_{2} \text { conversion }}{P}
$$

\section{3. 実験結果および考察}

パルス電源の直流電源の入力電圧を $180 \mathrm{~V}$ ，パルス周波数を $320 \mathrm{~s}^{-1}$ あるいは $2,060 \mathrm{~s}^{-1}$, 反応器の温度を室温あるいは $773 \mathrm{~K}$ の条件でメタンの酸化カップリング及び改質を行った。結果を Table 1 に示す，パルス周波数の低い $320 \mathrm{~s}^{-1}$ の場合に，室温での エチレンの選択率は最も高いが, $773 \mathrm{~K}$ ではエタンの選択率がエ

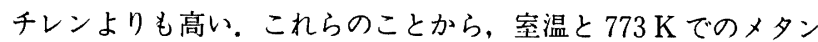


Table 1 Oxidative coupling and reforming of methane at room temperature and $773 \mathrm{~K}$

\begin{tabular}{|c|c|c|c|c|c|c|c|c|}
\hline \multirow{2}{*}{$\begin{array}{c}\text { temperature } \\
{[\mathrm{K}]}\end{array}$} & \multirow{2}{*}{$\begin{array}{c}F \\
{\left[\mathrm{~s}^{-1}\right]}\end{array}$} & \multirow{2}{*}{$\begin{array}{c}P \\
{[W]}\end{array}$} & \multicolumn{2}{|c|}{ conversion $[\%]$} & \multicolumn{4}{|c|}{ selectivity[\%] } \\
\hline & & & $\mathrm{CH}_{4}$ & $\mathrm{CO}_{2}$ & $\mathrm{CO}$ & $\mathrm{C}_{2} \mathrm{H}_{4}$ & $\mathrm{C}_{2} \mathrm{H}_{6}$ & $\mathrm{CH}_{3} \mathrm{OH}$ \\
\hline $\begin{array}{c}\text { room } \\
\text { temperature }\end{array}$ & 320 & 3.26 & 1.67 & 2.21 & 20.8 & 53.4 & 10.9 & 4.98 \\
\hline $\begin{array}{l}\text { room } \\
\text { temperature }\end{array}$ & 2060 & 26.4 & 18.8 & 11.3 & 17.0 & 63.7 & 11.1 & 5.81 \\
\hline 773 & 320 & 3.12 & 0.697 & 2.64 & 38.6 & 8.18 & 48.8 & 3.94 \\
\hline 773 & 2060 & 23.7 & 18.9 & 7.5 & 13.3 & 66.2 & 8.75 & 5.25 \\
\hline
\end{tabular}

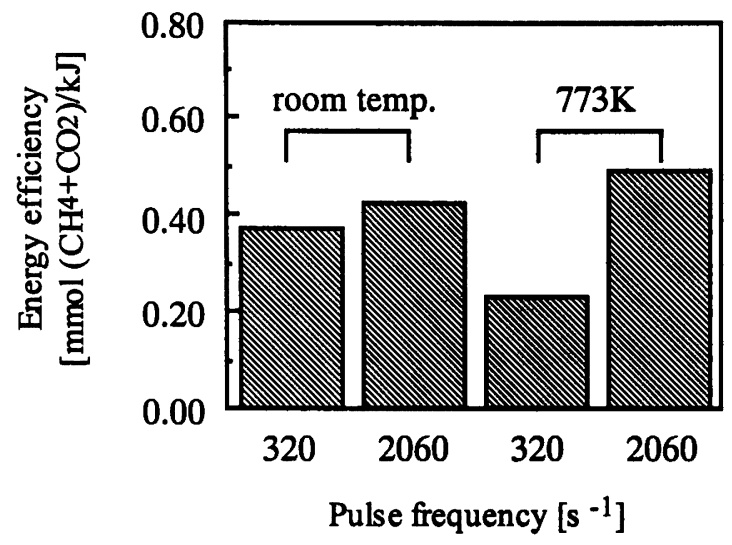

Fig. 1 Improvement of energy efficiency

酸化カップリング及び改質反応が異なると考えられる，パルス周 波数の高い $2,060 \mathrm{~s}^{-1}$ の場合には, 室温および $773 \mathrm{~K}$ 共にエチレ ンの選択率が高いことがわかる.

メタンと二酸化炭素のプラズマにおいては, 以下の反応（Eqs. (8)一(15)) などが起きていると考えられる:

$$
\begin{aligned}
& \mathrm{CH}_{4} \rightarrow \mathrm{CH}_{\mathrm{X}}+(4-\mathrm{X}) \mathrm{H} \quad \mathrm{X}=0-3 \\
& \mathrm{CH}_{3}+\mathrm{CH}_{3} \rightarrow \mathrm{C}_{2} \mathrm{H}_{6} \\
& \mathrm{CH}_{2}+\mathrm{CH}_{3} \rightarrow \mathrm{C}_{2} \mathrm{H}_{4}+\mathrm{H} \\
& \mathrm{CH}+\mathrm{CH}_{4} \rightarrow \mathrm{C}_{2} \mathrm{H}_{4}+\mathrm{H} \\
& \mathrm{H}+\mathrm{H} \rightarrow \mathrm{H}_{2} \\
& \mathrm{CO}_{2} \rightarrow \mathrm{CO}+\mathrm{O} \\
& \mathrm{O}+\mathrm{C}_{2} \mathrm{H}_{4} \rightarrow \mathrm{CH}_{3}+\mathrm{HCO} \\
& \mathrm{HCO}+\mathrm{O} \rightarrow \mathrm{CO}_{2}+\mathrm{H}
\end{aligned}
$$

エチレンは主に反応 Eqs.（10）と（11）から生成すると思われ る. パルス周波数が低いと反応温度の高い $(773 \mathrm{~K})$ 場合, エタン の選択率がエチレンより高い，また一酸化炭素の選択率は低温よ ク高い。これは高温の場合, 温度依存性の高い反応 Eq. (14) が早 くなり (Baulch et al., 1994), 生成したエチレンがさらに酸化さ れ，エタンや二酸化炭素の生成 (反応 Eqs. (9) と（15））に寄与す ると考えられる.

室温と $773 \mathrm{~K}$ の条件では, 水素の生成濃度, メタンの転化率及 び生成物選択率から計算した結果，水素の選択率はほほ $100 \%$ で あることが分かった。これは水が生成しないことを意味する。ま た生成物中に酸素生成が認められなかった，更に，パルス周波数 の高い $2,060 \mathrm{~s}^{-1}$ の場合, $773 \mathrm{~K}$ での二酸化炭素の転化率が室温よ り低くなった.これらのことから，二酸化炭素からの酸素は主に メタノールや一酸化炭素の生成に消費されたと考之られる.

各条件でのエネルギー効率を示す Fig. 1 から，室温および 773 $\mathrm{K}$ でエネルギー効製が $2,060 \mathrm{~s}^{-1}$ の場合は $320 \mathrm{~s}^{-1}$ の場合よりも 大である. 特に, $2,060 \mathrm{~s}^{-1}, 773 \mathrm{~K}$ では反応に使われた電力が少な
いため，エネルギー効率は最大であった．従って，さらに高いパ ルス周波数と高い反応温度の条件を用いれば, エネルギー効率の 向上が期待できる.

パルスプラズマによるメタン・二酸化炭素のカップリング及 び改質を行うことができた. 高いパルス周波数 $\left(2,060 \mathrm{~s}^{-1}\right)$ と高 い反応温度 $(773 \mathrm{~K})$ で単位消費電力あたりのメタンと二酸化炭素 の転化量が最も大きいという実験結果を得た。また主な生成物は エチレン, 一酸化炭素, 水素及びメタノールであるため, エチレ ンとメタノールを反応ガスから分離した後, 一酸化炭素と水素か ら触媒を用いたメタノール合成が可能である. 今後, パルス周波 数をさらに上げることによって, エネルギー効率を向上し, 本シ ステムの実用化を図る。

[謝 辞] 本研究は新エネルギー・産業技術総合開発機構 (NEDO)の 委託を受けて行われた。ここに記して謝意を表します。

\section{Nomenclature}

$F \quad=$ pulse frequency

$F_{\mathrm{CH}_{4}}=$ flow rate of methane

$F_{\mathrm{CO}_{2}}=$ flow rate of carbon dioxide

$I_{1} \quad=$ discharge current at discharge time $t_{1}$

$P \quad=$ energy used for discharge $[\mathrm{mol} / \mathrm{s}]$

$t_{1} \quad$ discharge time

$V_{1}$ = discharge voltage at discharge time $t_{1}$

\section{Literature cited}

Baulch, D. L., C. J. Cobos, R. A. Cox, P. Frank, G. Hayman, TH. Just, J. A. Kerr, T. Murrells, M. J. Pilling, J. Troe, R. W. Walker, and J. Warnatz; "Summary Table of Evaluated Kinetic Data for Combustion Modeling: Supplement 1," Combust. Flame, 98, 59-79 (1994)

Liu, C., A. Marafee, R. Mallison and L. Lobban; "Methane Conversion to Higher Hydrocarbons in a Corona Discharge over Metal Oxide Catalysts with OH Groups," Appl. Catal. A, 164, 21-23 (1997)

Shepelev, S. S., H. D. Gesser, and N. R. Hunter; "Light Paraffin Oxidative Conversion in a Silent Electric Discharge," Plasma Chem. Plasma Proc., 13, 479-488 (1993)

Suib, S. L. and R. P. Zerger; "A Direct, Continuous, Low-Power Catalytic Conversion of Methane to Higher Hydrocarbons via Microwave Plasmas," J. Catal., 139, 383-391 (1993)

Tominaga, H. and K. Yoshida ; New Technology of Methanol Production, p. 36, Science Forum, Tokyo, Japan (1987)

Yao, S. L., F. Ouyang, A. Nakayama, E. Suzuki, M. Okumoto and A. Mizuno; "Influences of Frequency on Methane Selective Oxidation in a Pulsed Plasma," J. Inst. Electrostat Jpn., 24, 163-164 (2000) 


\title{
Coupling and Reforming of Methane with Carbon Dioxide in
}

\section{a Pulsed Plasma}

\author{
SHUILIANG YAO ${ }^{1}$, FENG OUYANG ${ }^{1}$, AKIRA NAKAYAMA ${ }^{1}$, \\ EIJI SUZUKI ${ }^{1}$, MAMORU OKUMOTO ${ }^{2}$ and AKIRA MIZUNO ${ }^{2}$
}

${ }^{1}$ Catalysis Science Laboratory, Research Institute of Innovative Technology for the Earth, Kyoto 619-0292

${ }^{2}$ Department of Ecological Engineering, Toyohashi University of Technology, Aichi 441-8580

Key words: methane coupling, methane reforming, ethylene production, carbon dioxide.

Coupling and reforming of methane with carbon dioxide were studied at room temperature and 773 $\mathrm{K}$ in a pulsed plasma. Methane and carbon dioxide could be converted mainly to ethylene, carbon monoxide, and hydrogen at room temperature. At $773 \mathrm{~K}$, the main product was ethane at a low pulse frequency and ethylene at a high pulse frequency. The energy efficiency can be significantly improved by using a high pulse frequency and high temperature. 